\title{
Pengungkapan Corporate Social Responsibility dan Price to Book Value: Pengujian Efek Moderasi Good Corporate Governance
}

\author{
Ni Made Ardi Naraswari ${ }^{1}$ \\ Fakultas Ekonomi dan Bisnis \\ Universitas Udayana, Indonesia
}

\author{
Ni Made Dwi Ratnadi ${ }^{2}$ \\ Fakultas Ekonomi dan Bisnis \\ Universitas Udayana, Indonesia
}

\begin{abstract}
Surel : ardiinaraswarii@yahoo.com
ABSTRAK

Price to book value (PBV) merupakan perbandingan antara harga saham dengan nilai buku per lembar saham. Penelitian ini bertujuan untuk menguji secara empiris pengaruh pengungkapan corporate social responsibility pada price to book value dan peran good corporate governance dalam memperkuat pengaruh pengungkapan corporate social responsibility pada price to book value. Sampel ditentukan dengan menggunakan metode nonprobability sampling dengan teknik purposive sampling. Dari purposivesampling diperoleh sebanyak 19 sampel dari tahun 2016-2019, sehingga diperoleh 52 pengamatan. Teknik analisis yang digunakan adalah analisis regresi moderasi (MRA). Hasil analisis menunjukan bahwa pengungkapan corporate social responsibility berpengaruh negatif dan tidak signifikan pada price to book value dan good corporate governance memperkuat pengaruh pengungkapan corporate social responsibility pada price to book value.
\end{abstract}

Kata Kunci: Pengungkapan Corporate Social Responsibility; Price to Book Value; Good Corporate Governance.

\section{Disclosure of Corporate Social Responsibility and Price to Book Value: Testing The Effect of Moderation of Good Corporate Governance}

\begin{abstract}
Price to book value (PBV) is a comparison between the stock price and the book value per share. This study aims to empirically examine the effect of corporate social responsibility disclosure on price to book value and the role of good corporate governance in streng thening the effect of corporate social responsibility disclosure on price to book value. The sample was determined by using nonprobability sampling method with purposive sampling technique. From purposivesampling, 19 samples were obtained from 2016-2019, so that 52 observations were obtained. The analysis technique used is moderated regression analysis (MRA). The results of the analysis show that the disclosure of corporate social responsibility has a negative and insignificant effect on price to book value and good corporate governance strengthens the effect of corporate social responsibility disclosure on price to book value.
\end{abstract}

Keywords: Corporate Social Responsibility Disclosure; Price to Book Value; Good Corporate Governanance.

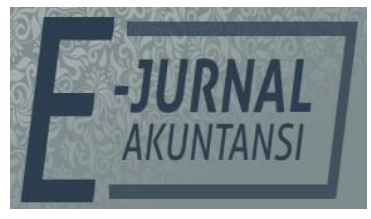

e-ISSN 2302-8556

Vol. 31 No. 11

Denpasar, November 2021

Hal. 2704-2717

DOI:

10.24843/EJA.2021.v31.i11.p03

PENGUTIPAN:

Naraswari, N. M. A., \& Ratnadi, N. M. D. (2021).

Pengungkapan Corporate Social Responsibility dan Price to Book Value : Pengujian Efek

Moderasi Good Corporate Governance. E-Jurnal Akuntansi, 31(11), 2704-2717

RIWAYAT ARTIKEL: Artikel Masuk: 15 Januari 2021 Artikel Diterima: 25 Maret 2021

Artikel dapat diakses: https:/ / ojs.unud.ac.id/index.php/Akuntansi/index 


\section{PENDAHULUAN}

Dewasa ini persaingan global dan perkembangan dunia usaha semakin ketat dan pesat. Perkembangan ini diiringi dengan persaingan usaha yang begitu ketat dan kompetitif. Dalam melaksanakan strategi untuk memenangkan persaingan, kebutuhan pendanan merupakan salah satu kendala yang dihadapi perusahaan. Oleh karena hal tersebut pasar modal memberikan cara yang bisa dipertimbangkan dalam masalah pendanaan yaitu dengan cara mengganti status perusahaan dari perusahaan tertutup menjadi perusahaan terbuka melalui penawaran saham kepada publik (go public) dan mencatatkan sahamnya di PT Bursa Efek Indonesia (perusahaan tercatat) (Melani \& Wahidahwati, 2017). Dalam melakukan keputusan investasi di pasar modal, investor memerlukan informasi tentang penilaian saham. Penilaian yang berhubungan dengan saham terdiri dari 3 jenis yaitu nilai buku (book value), nilai pasar (market value) dan nilai intrinsik (intrinsic value) (Marlina, 2013).

Mengetahui dan memahami ketiga nilai tersebut merupakan hal penting yang harus dilakukan oleh investor dalam pengambilan keputusan investasi saham, yang dimana hal tersebut merupakan informasi yang sangat penting dikarenakan mampu memberi pengetahuan kepada investor dalam mengetahui saham-saham mana yang bertumbuh dan murah (Hidayati, 2010). Faktor fundamental merupakan salah satu faktor yang dapat mempengaruhi harga saham serta dapat mengestimasi harga saham di masa yang akan datang. Salah satu pendekatan dalam menentukan penilaian saham adalah dengan melihat Price to Book Value (PBV) (Marlina, 2013). Price to Book Value (PBV) adalah perbandingan antara harga saham dengan nilai buku per lembar saham. Harga saham perusahaan dapat diketahui berada di atas atau di bawah nilai bukunya setelah dilakukan perbandingan tersebut (Purnamaningsih \& Wirawati, 2014).

Perusahaan yang dapat beroperasi dengan baik, umumnya memiliki nilai PBV diatas satu, yang menunjukkan nilai pasar saham lebih tinggi dari nilai bukunya. Tinggi rendahnya rasio ini menunjukan kepercayaan pasar terhadap prospek perusahaan tersebut (Silalahi, 2014). Semakin tinggi rasio Price to Book Value dapat diartikan semakin berhasil perusahaan menciptakan nilai bagi pemegang saham, sehingga perusahaan di masa yang akan datang dianggap memiliki nilai tambah dan mampu memberi return yang baik kepada investor apabila memiliki nilai PBV yang tinggi. Hal ini akan mampu menarik investor melalui pemberian sinyal positif dari perusahaan, bahwa modal yang mereka berikan, akan mampu menghasilkan keuntungan di masa yang akan datang, sehingga investor tertarik untuk berinvestasi pada perusahaan tersebut, melalui pembelian saham perusahaan. Jika terdapat banyak investor yang membeli saham suatu perusahaan, maka akan menguntungkan pemegang saham perusahaan (Savitri \& Mimba, 2016).

Pada tahun 2019 tercatat sebanyak 713 perusahaan yang tercatat di Bursa Efek Indonesia, tercatat beberapa perusahaan di Indonesia yang sudah go public dengan pencapain penjualan saham tertinggi. Kpercayaan investor atau calon investor terhadap peruahaan akan semakin baik apabila harga saham yang tinggi dapat dipertahankan sehingga akan dapat meningkatkan citra perusahaan. Sebaliknya, apabila harga saham mengalami penurunan secara terus menerus maka akan dapat menurunkan citra perusahaan tersebut dimata para investor 
atau calon investor yang berdampak kepada pandangan prospek perusahaan di masa depan (Suffah \& Riduwan, 2016). Indeks Harga Saham Gabungan (IHSG) mengakhiri tahun 2019 dengan kinerja positif, mencetak pergerakan positif dengan penguatan $1,7 \%$. Oleh karena itu, terdapat banyak investor yang ingin untuk menanamkan modalnya di perusahaan yang terdaftar di BEI. Namun penurunan index harga saham gabungan sudah dua kali mengalami penurunan selama 2020 akibat pandemi Covid-19. Pada maret 2020 merupakan penurunan pertama terjadi yang menyebabkan indeks turun sebesar $37,33 \%$ year to date, sehingga hal ini dapat menurunkan kepercayaan investor untuk berinvestasi pada perusahaan tersebut, sehingga permasalahan tersebut menjadi fenomena yang menarik untuk diteliti dengan tujuan mengetahui apakah fluktuasi yang sebelumnya dialami oleh perusahaan dapat dipulihkan oleh faktor-faktor tertentu.

Investor mempertimbangkan beberapa faktor dalam pengambilan keputusan investasi, yaitu melalui faktor keuangan dan faktor non keuangan dari perusahaan, faktor utama yang mempengaruhi prospek perusahaan kedepannya adalah faktor keuangan. Banyak perusahaan yang hanya menjadikan faktor keuangan saja sebagai tolak ukur faktor yang berpengaruh penting terhadap prospek perusahaan di masa depan (Susanto \& Subekti, 2017). Namun saat ini, prospek perusahaan di masa depan tidak hanya dipengaruhi oleh faktor keuangan, faktor non keuangan juga mampu memberikan dampak yang cukup besar pada kinerja perusahaan yang berpengaruh pada peningkata citra perusahaan sehingga berdampak terhadap pandangan investor pada prospek perusahaan kedepannya, untuk dapat mempertahankan suatu perusahaan dapat terus mengalami pertumbuhan yang berkelanjutan, suatu perusahaan tidak cukup jika hanya mengedepankan kondisi keuangan semata (Umbara \& Suryanawa, 2014).

Faktor non keuangan yang dimagsud yakni, corporate social responsibility (Pertiwi \& Pratama, 2011). corporate social responsibility (CSR) didefinisikan merupakan sebuah komitmen berkelanjutan dari perusahaan untuk berkontribusi serta memajukan peningkatan ekonomi sambil mengembangkan kualitas hidup masyarakat dan lingkungan. Corporate social responsibility merupakan sebuah kewajiban, hal tersebut didukung dengan adanya Undang-Undang Republik Indonesia (UU RI) Nomor 40 Tahun 2007 mengenai Perseroan Terbatas (PT) dan UU RI Nomor 25 Tahun 2007 mengenai Penanaman Modal. Berdasarkan peraturan yang telah diatur oleh pemerintah, setiap perusahaan (high profile maupun low profile) yang terdaftar di Bursa Efek Indonesia diwajibkan untuk melakukan dan mengungkapkan tanggung jawab sosial (CSR) (Umbara \& Suryanawa, 2014). Kesadaran atas pentingnya pengungkapan tanggung jawab sosial perusahaan (corporate social responsibility/CSR) dilandasi pemikiran bahwa perusahaan beroperasi tidak hanya untuk keuntungan semata atau hanya mengedepankan faktor ekonomi kepada pemegang saham, akan tetapi juga harus memperhatikan kewajiban terhadap pihak-pihak lain yang berkepentingan (Wijaya, 2012).

Perbedaan temuan penelitian terkait pengaruh pengungkapan corporate social responsibility pada Price to Book Value menunjukkan adanya research gap, sehingga diperlukan adanya penelitian kembali. Ketidakkonsistenan hasil penelitian diduga ada variabel lain yang memoderasi hubungan pengungkapan 
corporate social responsibility pada Price to Book Value yaitu Good Corporate Governance. Good Corporate Governance (GCG) adalah sistem dan struktur yang baik untuk mengelola perusahaan dengan tujuan meningkatkan nilai pemegang saham serta mengakomodasi para stakeholders perusahaan (Siboro, 2007). Pelaksanaan Good Corporate Governance yang baik dan sesuai dengan peraturan yang berlaku akan membuat investor merespon secara positif terhadap kinerja perusahaan sehingga akan membuat investor percaya terhadap prospek perusahaan. Perusahaan yang mengungkapkan corporate social responsibility nantinya akan mampu memberikan citra yang baik bagi perusahaannya. Loyalitas kosumen akan semakin tinggi apabila pengungkapan corporate social responsibility yang dilakukan perusahaan semakin baik, sehingga akan berdampak pada peningkatan penjualan yang dapat memberikan nilai tambah bagi perusahaan (Susanto \& Subekti, 2017).

Teori persinyalan (signalling theory) membahas terkait sebuah perusahaan mampu menyampaikan sinyal kepada investor melalui pengungkapan informasi. Informasi yang dipublikasikan sebagai suatu pengumuman akan memberikan signal bagi investor dalam pengambilan keputusan investasi. Perusahaan yang menginformasikan berita baik (good news) mengenai kinerja perusahaan terhadap investor salah satunya terkait pengungkapan CSR yang dilakukan perusahaan maka dapat menjadikan sinyal positif terkait tingkat pengembalian keuntungan investasi yang akan diperoleh oleh investor, sehingga berpengaruh terhadap kenaikan harga saham dan meningkatnya PBV perusahaan (Dewi et al., 2014). Hal tersebut juga didukung dengan adanya teori stakeholder (stakeholder theory) yang menyatakan bahwa perusahaan bukanlah entitas yang hanya beroperasi untuk kepentingannya sendiri serta hanya berorientasi pada keuntungan semata, tetapi harus mampu memberikan manfaat bagi stakeholdernya (Nahda \& Harjito, 2011). Dengan demikian tanggungjawab perusahaan yang umumnya hanya berpijak pada single bottom line, harus bergeser dengan memperhitungkan faktor-faktor sosial dan lingkungan (triple bottom line). Apabila perusahaan dapat memberi manfaat kepada stakeholder maka akan timbul kepuasan bagi stakeholder yang akan menciptakan citra perusahaan yang berdampak pada penjualan saham perusahaan sehingga berpengaruh terhadap peningkatan PBV perusahaan (Bayu et al., 2015).

Berdasarkan penelitian terdahulu (Gde et al., 2013), (Ardimas et al., 2014), (Nahda \& Harjito, 2011), (Wijaya, 2012), dan (Sunarsih et al., 2019) menyatakan bahwa pengungkapan CSR berpengaruh pada Price to Book Value perusahaan. Berdasarkan uraian tersebut, maka dapat dirumuskan hipotesis sebagai berikut. $\mathrm{H}_{1}$ : Pengungkapan Corporate Social Responsibility Berpengaruh Positif pada Price to Book Value.

Teori keagenan menjelaskan bahwa adanya hubungan kerja antara pihak yang memberi wewenang, yaitu investor, dan pihak yang menerima wewenang (agent), atau manajer (Harahap, 2018). Di dalam suatu perusahaan terdapat dua kepentingan yang berbeda di mana setiap pihak berusaha mencapai tingkat kemakmuran yang dikehendaki/kepentingan pribadi. Perbedaan kepentingan antara pemilik dan agen terjadi karena kemungkinan agen tidak selalu berbuat sesuai dengan kepentingan pemilik sehingga memicu agency problem. Perbedaan kepentingan antara agen dan pemilik dapat diminimalisir dengan melaksanakan 
pengawasan yang dapat menyelaraskan berbagai kepentingan yang ada di dalam perusahaan dengan menerapkan Good Corporate Governance. Penerapan GCG yang dilakukan oleh perusahaan akan dapat mengurangi asimetri informasi yang terjadi (Nahda \& Harjito, 2011). Berdasarkan penelitian terdahulu (Gdeet al., 2013); (Wijaya, 2012); menunjukn hasil bahwa Good Corporate Governance memperkuat pengaruh pengungkapan corporate social responsibility pada Price to Book Value Perusahaan. Berdasarkan uraian tersebut, maka dapat dirumuskan hipotesis sebagai berikut.

$\mathrm{H}_{2}$ : Good Corporate Governance Memperkuat Pengaruh Pengungkapan Corporate Social Responsibility pada Price to Book Value.

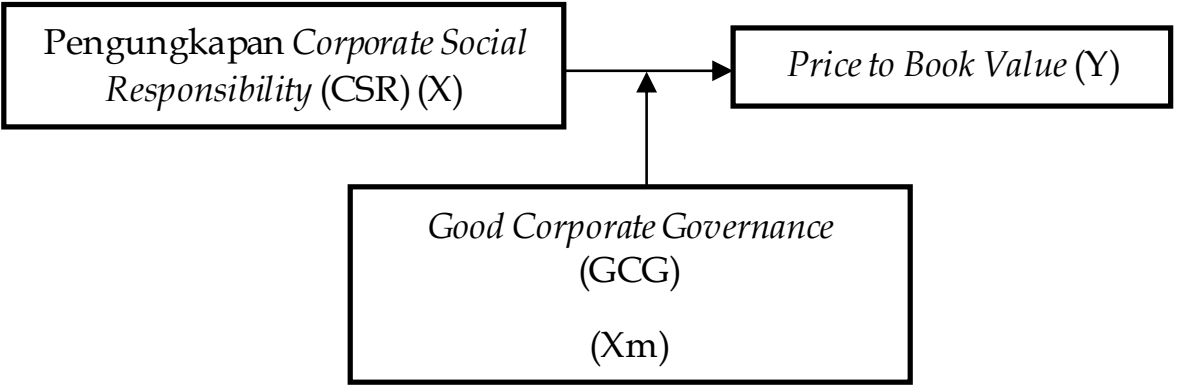

Sumber: Data Penelitian, 2020

Gambar 1. Kerangka Konseptual

\section{METODE.PENELITIAN}

Penelitian ini menggunakan pendekatan bersifat kuantitatif berbentuk asosiatif. Variabel independen yang diteliti yakni pengungkapan corporate social responsibility $(\mathrm{X})$ sedangkan variabel dependen yakni Price to Book Value (Y) dan variabel moderasi yakni Good Corporate Governance $(\mathrm{M})$. Penelitian dilakukan pada seluruh perusahaan yang terdaftar di Bursa Efek Indonesia tahun 2016-2019. Penelitian ini menggunakan data sekunder yang bersumber dari situs resmi BEI yaitu $w w w$.idx.co.id berupa laporan tahunan periode 2016-2019 serta majalah SWA yang dikembangkan IICG berupa data CGPI. Penelitian ini dilakukan pada seluruh perusahaan yang terdaftar di BEI, alasan menggunakan seluruh perusahaan yang terdaftar di BEI (go public) dikarenakan, perusahaan yang terdaftar di BEI (go public) merupakan perusahaan yang sahamnya diperjual belikan di Bursa, sehingga setiap saat dapat diperoleh valuasi tentang nilai saham perusahaan, dikarena pergerakan harga saham perusahaan yang di transaksikan di bursa dapat dinilai oleh investor terhadap perusahaan yang sudah go public. Setiap peningkatan kinerja perusahaan, pada dasrnya akan memberikan dampak terhadap harga saham di Bursa, yang akan berpengaruh terhadap peningkatan citra perusahaan dan berdampak terhadap pandangan investor pada prospek perusahaan keepannya. Objek penelitian ini adalah price too book value yang diproksikan dengan menggunakan rasio Price to Book Value (PBV).

Pengungkapan tanggung jawab social perusahaan didefinisikan sebagai salah satu mekanisme yang mengkomunikasikan perusahaan dengan stakeholders (Badjuri, 2011). Pengukuran pengungkapan CSR dalam penelitian ini berdasarkan 
pada standar GRI (Global Reporting Initiative) yang terdiri dari 3 indikator, yaitu ekonomi, lingkungan dan sosial. Saat ini standar GRI versi terbaru, yaitu GRI 4.0. $\frac{\sum x i j}{\mathrm{Nj}}$

CSRIj = Corporate Social Responsibility Disclosure Index perusahaan $\mathrm{j}$

$\Sigma x i j=$ Jumlah indikator CSR yang diungkapkan perusahaan perbankan $\mathrm{j}$ tahun i

$\mathrm{Nj} \quad=$ Jumlah indikator menurut GRI 4.0

Price to Book Value (PBV) merupakan perbandingan antara harga saham dengan nilai buku per lembar saham. Investor akan percaya terhadap prospek perusahaan di masa depan apabila suatu perusahaan memiliki PBV yang tinggi (Mahardhika \& Roosmawarni, 2016). Adapun indikator yang digunakan untuk mengukur variable ini adalah skala rasio PBV (Price to Book Vaue).

PBV $\frac{\text { Harga Saham }}{\text { Nilai Buku Saham. }}$

Good Corporate Governance merupakan tata kelola yang baik. GCG adalah sebuah pedoman bagi manajer untuk mengelola perusahaan dalam kinerja terbaik. Melalui penerapan GCG, para manajer akan diminta untuk membuatnya keputusan keuangan yang dapat memiliki manfaat bagi pemangku kepentingan). Dalam penelitian ini, indikator pengukuran untuk GCG diukur dengan menggunakan instrumen yang telah dikembangkan oleh IICG berupa CGPI yang berisi skor hasil survey mengenai penerapan Corporate Governance pada perusahaan yang terdaftar di BEI. Skor sesuai dengan rating yang diperoleh dari CGPI yaitu, Sangat Terpercaya $(85,00-100)$, Terpercaya $(70,00-84,99)$ dan Cukup Terpercaya $(55,00-69,99)$

Metode dokumentasi merupakan metode pengumpulan data yang digunakan dalam penelitian ini, berupa pengumpulan data yang menggunakan jurnal-jurnal, buku-buku, laporan tahunan yang diperoleh melalui website www.idx.co.id dan Majalah SWA yang dikembangkan oleh IICG berupa CGPI. Teknik analisis data yang digunakan untuk mengetahui dan menganalisis PBV perusahaan yang terdaftar di BEI pada tahun 2016-2019 yaitu dengan analisis regresi modrasi (MRA) dengan bantuan program aplikasi SPSS (Statistical Product dan Service Solutions) (Ghozali, 2018). Analsisi statistik deskriptif serta asumsi klasik (uji normalitas, uji autokolerasi, uji heteroskedastisitas) dilakukan terlebih dahulu sebelum melakukan analisis regresi moderasi (MRA).

Persamaan analisis regresi moderasi (MRA):

$Y=\alpha+\beta_{1} X+\beta_{2} M+\beta_{3} X M+\varepsilon$

Keterangan :

$\begin{array}{ll}\mathrm{Y} & =\text { Price to Book Value } \\ \mathrm{A} & =\text { Konstanta } \\ \beta_{1}-\beta_{3} & =\text { Koefisien Regresi } \\ \mathrm{X} & =\text { Pengungkapan Corporate Social Responsibility } \\ \mathrm{M} & =\text { Good Corporate Governance }\end{array}$


HASIL DAN PEMBAHASAN

Tabel 1. Proses Seleksi Sempel Berdasarkan Kriteria

\begin{tabular}{lllllll}
\hline No & \multicolumn{1}{c}{ Keterangan } & \multicolumn{4}{c}{ Tahun } & Total \\
\cline { 2 - 6 } 1 & 2016 & 2017 & 2018 & 2019 & \\
\hline & $\begin{array}{l}\text { Perusahaan yang terdaftar di } \\
\text { BEI periode 2016-2019 }\end{array}$ & 488 & 483 & 628 & 713 & 2.312 \\
2 & $\begin{array}{l}\text { Perusahaan yang terdaftar di } \\
\text { BEI yang tidak termasuk } \\
\text { dalam pemeringkatan CGPI } \\
\text { 2016-2019(Tidak berturut- } \\
\text { turut) }\end{array}$ & $(473)$ & $(468)$ & $(615)$ & $(702)$ & $(2.25$ \\
$\begin{array}{l}\text { Perusahaan yang mengalami } \\
\text { kerugian periode2016-2019 }\end{array}$ & $(1)$ & $(1)$ & $(0)$ & $(0)$ & $(0)$ \\
& & & & & & \\
& Jumlah Sampel Penelitian & 14 & 14 & 13 & 11 & 52 \\
\hline
\end{tabular}

Sumber: Data Penelitian, 2020

Berdasarkan proses seleksi sampel yang disajikan pada Tabel 1, diperoleh sampel sebanyak 19 perusahaan selama empat tahun periode dengan total 52 pengamatan.

Tabel 2. Hasil Uji Analisis Statistik Deskriptif

\begin{tabular}{|c|c|c|c|c|c|}
\hline \multicolumn{6}{|c|}{ Descriptive Statistics } \\
\hline & $N$ & Minimum & Maximum & Mean & $\begin{array}{c}\text { Std. } \\
\text { Deviation }\end{array}$ \\
\hline $\begin{array}{l}\text { Pengungkapan } \\
\text { CSR }\end{array}$ & 52 & 0,418 & 0,659 & 0,523 & 0,058 \\
\hline GCG & 52 & 71,440 & 94,860 & 85,893 & 5,271 \\
\hline PBV & 52 & 0,296 & 4,092 & 1,443 & 0,941 \\
\hline Valid N (listwise) & \multicolumn{5}{|l|}{52} \\
\hline $\begin{array}{l}\text { CSRI dengan mer } \\
\text { menjelaskan bahn } \\
\text { 0,418 dengan dite } \\
\text { 2016, PT Bukit As } \\
\text { 2018. Nilai maxim } \\
\text { Bank Central Asi } \\
\text { pengungkapan CS } \\
\text { bahwa standar } \\
\text { menunjukkan bah }\end{array}$ & $\begin{array}{l}\text { can sta } \\
\text { ungka } \\
\text { eh PT } \\
\text { Pada } \\
\text { gungk } \\
\text { ada to } \\
\text { ar } 0,52 \\
\text { lebih }\end{array}$ & $\begin{array}{l}\text { lar GRI 4.0 } \\
\text { n CSR (X) } \\
\text { nk Rakyat I } \\
\text { hun 2016, P } \\
\text { an CSR seb } \\
\text { an 2018. N } \\
\text { dengan stan } \\
\text { ndah dibar } \\
\text { lyebaran da }\end{array}$ & $\begin{array}{l}\text { Hasil dari } \\
\text { ang memp } \\
\text { lonesia (Per } \\
\text { Bakrie and } \\
\text { sar } 0,659 \text { ya } \\
\text { ii rata-rata } \\
\text { ar deviasi } 0 \\
\text { ingkan nil }\end{array}$ & $\begin{array}{l}\text { i statist } \\
\text { nyai nil } \\
\text { ero) Tbl } \\
\text { Brother } \\
\text { g ditem } \\
\text { mean) } \\
\text { 58. Dap }\end{array}$ & $\begin{array}{l}\text { k deskriptif } \\
\text { i minimum } \\
\text { Pada tahun } \\
\text { pada tahun } \\
\text { pati oleh PT } \\
\text { ari variabel } \\
\text { t dijelaskan } \\
\text { ta. Hal ini }\end{array}$ \\
\hline
\end{tabular}


variasi data CSR yang rendah dan tidak menyebabkan data bias pada perusahaan yang terdaftar di BEI yang dijadikan sebagai sampel penelitian.

Variabel Good Corporate Governance diukur dengan menggunakan instrumen yang telah dikembangkan oleh IICG berupa CGPI yang berisi skor hasil survey mengenai penerapan Corporate Governance pada perusahaan yang terdaftar di BEI. Hasil dari uji statistik deskriptif menjelaskan bahwa variabel Good Corporate Governance $\left(\mathrm{X}_{2}\right)$ memiliki nilai minimum sebesar 71,440 ditempati oleh PT Pembangunan Jaya Ancol Tbk. Pada tahun 2017. Nilai maximum GCG sebesar 94,860 ditempati oleh PT Bank Mandiri (Persero) Tbk. Pada tahun 2019. Nilai ratarata (mean) dari variabel GCG sebesar 85,893 dengan standar deviasi 5,277. Dapat dijelaskan bahwa standar deviasi lebih rendah dibandingkan nilai rata-rata. Hal ini menunjukkan bahwa hasil penyebaran dari variabel data Good Corporate Governance yang kecil atau variasi data Good Corporate Governance yang rendah dan tidak menyebabkan data bias pada yang terdaftar di BEI yang dijadikan sebagai sampel penelitian.

Variabel Price to Book Value diukur dengan skala rasio PBV (price to book vaue). Hasil dari uji statistik deskriptif menjelaskan bahwa variabel Price to Book Value memiliki nilai minimum sebesar 0,296 ditempati oleh PT Bank Rakyat Indonesia (Persero) Tbk. Pada tahun 2016. Nilai maximum sebesar 4,092 ditempati oleh PT Bank Central Asia Tbk. Pada tahun 2018. Nilai rata-rata (mean) dari variabel PBV sebesar 1,44364 dengan standar deviasi 0,941. Dapat dijelaskan bahwa standar deviasi lebih rendah dibandingkan nilai rata-rata. Hal ini menunjukkan bahwa hasil penyebaran dari variabel data Price to Book Value yang kecil atau variasi data Price to Book Value yang rendah dan tidak menyebabkan data bias pada yang terdaftar di BEI yang dijadikan sebagai sampel penelitian.

Tabel 3. Rangkuman Uji Asumsi Klasik

\begin{tabular}{lll}
\hline Uji Normalitas & Variabel Uji Autokolerasi & Uji Heteroskedastisitas
\end{tabular}

\begin{tabular}{lccc}
\hline Signifikansi $=$ & Pengungkapan CSR & Dw $=1,207$ & 0,851 \\
0,200 & GCG & $\mathrm{du}=1,676$ & 0,651 \\
& Pengungkapan CSR ${ }^{*}$ GCG & $\mathrm{dl}=1,433$ & 0,812 \\
\hline
\end{tabular}

Sumber: Data Penelitian, 2020

Hasil uji normalitas yang disajikan pada Tabel 3. dengan menggunakan Kolmogorov Smirnov Asymp. Sig. (2-tailed) sebesar 0,200 sehingga dapat disimpulkan bahwa data berdistribusi normal. Hasil Uji Autokolerasi yang disajikan pada Tabel 3, menunjukkan hasil dari nilai Durbin-Wason sebesar 1,207 dengan taraf signifikansi $5 \%$ untuk jumlah sampel $(n)=52$ dan jumlah variabel independen $(\mathrm{k})=3$, sehingga diperoleh nilai $\mathrm{dL}=1,433$ dan nilai $\mathrm{d} U=1,676$ Sehingga dapat dirumuskan $-2 \leq 1,207 \leq 2$, dapat disimpulkan bahwa model regresi tidak terjadi autokorelasi. Hasil Uji Heteroskedastisitas yang disajikan pada Tabel 3. menunjukan bahwa nilai signifikansi pengungkapan CSR sebesar 0,851, Good Corporate Governance sebesar 0,651 dan interaksi antara pengungkapan CSR dengan GCG sebesar 0,812. Hasil uji tersebut mempunyai nilai signifikansi yang lebih besar dari 0,05, sehingga dapat disimpulkan bahwa tidak terjadi heteroskedastisitas. 
Tabel 4. Hasil Analisis Regresi Moderasi (MRA)

\begin{tabular}{|c|c|c|c|c|c|c|}
\hline & \multirow{2}{*}{ Model } & \multicolumn{2}{|c|}{$\begin{array}{l}\text { Unstandardized } \\
\text { Coefficients }\end{array}$} & \multirow{2}{*}{$\begin{array}{c}\text { Standardize } \\
\text { Coefficients }\end{array}$} & \multirow[b]{2}{*}{$\mathrm{t}$} & \multirow[b]{2}{*}{ Sig. } \\
\hline & & B & Std. Error & & & \\
\hline \multirow[t]{4}{*}{1} & (Constant) & 16,910 & 8,497 & & 1,990 & 0,052 \\
\hline & $\begin{array}{l}\text { PENGUNGKAPAN } \\
\text { CSR }\end{array}$ & $-33,374$ & 16,813 & $-2,057$ & $-1,985$ & 0,053 \\
\hline & GCG & $-0,264$ & 0,098 & $-1,480$ & $-2,701$ & 0,010 \\
\hline & $\begin{array}{l}\text { PENGUNGKAPAN } \\
{\text { CSR }{ }^{*} \text { GCG }}\end{array}$ & 0,548 & 0,193 & 3,748 & 2,842 & 0,007 \\
\hline \multicolumn{7}{|c|}{ Adjusted $\mathrm{R}^{2}=0,840$} \\
\hline \multicolumn{7}{|c|}{ F Hitung $=90,192$} \\
\hline \multicolumn{7}{|c|}{ Signifikansi $\mathrm{F}=0,000$} \\
\hline \multicolumn{7}{|c|}{ a. Dependent Variable:PBV } \\
\hline \multicolumn{7}{|c|}{ Sumber: Data Penelitian, 2020} \\
\hline \multicolumn{7}{|c|}{$\begin{array}{l}\text { Terdapat persamaan regresi yang di dapatkan dari hasil analisis moderasi } \\
\text { (MRA) yang disajikan pada Tabel 4, yaitu sebagai berikut. } \\
Y=16910-0.264 \mathrm{M}+0.548 \mathrm{XM}\end{array}$} \\
\hline
\end{tabular}

Berdasarkan persamaan regresi, maka dapat diinterpretasikan yaitu, Nilai konstanta sebesar 16,910 memiliki arti apabila variabel pengungkapan corporate social responsibility $(\mathrm{X})$, Good Corporate Governance $(\mathrm{M})$ dan interaksi antara pengungkapan corporate social responsibility dengan Good Corporate Governance (XM) konstan, maka nilai Price to Book Value (Y) perusahaan meningkat sebesar 16,910 persen, Nilai koefisien regresi Good Corporate Governance (M) sebesar -0,624 memiliki arti apabila Good Corporate Governance meningkat sebesar 1 persen dengan anggapan variabel lainnya konstan, maka Price to Book Value (Y) perusahaan menurun sebesar 0,624 persen dan Nilai koefisien regresi pengungkapan CSR ${ }^{\star}$ GCG sebesar 0,548 , memiliki arti apabila setiap interaksi pengungkapan CSR dengan Good Corporate Governance (GCG) meningkat sebesar 1 persen dengan variabel lainnya konstan, maka Price to Book Value $(Y)$ perusahaan meningkat 0,548 persen.

Berdasarkan Tabel 4. diperoleh nilai adjusted $\mathrm{R}^{2}$ sebesar 0,840. Hal ini dapat diartikan bahwa sebesar $84 \%$ variance Price to Book Value dapat dijelaskan oleh variabel pengungkapan CSR dan Good Corporate Governance. Sedangkan sisanya yaitu sebesar $16 \%$ variance Price to Book Value dipengaruhi variance atau faktorfaktor lain diluar model regresi yang digunakan pada model penelitian. Hasil uji kelayakan model yaitu nilai F hitung yang disajikan pada Tabel 4, sebesar 90,192 dengan nilai signifikansi yakni sebesar 0,000. Nilai signifikansi tersebut lebih kecil dari nilai $\mathrm{a}=0,05$, yang dapat diartikan bahwa model persamaan regresi linear ini layak untuk digunakan. Hasil ini memberikan arti bahwa variabel independen pengungkapan corporate social responsibility dan good coporate governance mampu memberikan prediksi atau penjelasan terhadap fenomena Price to Book Value perusahaan yangterdaftar di Bursa Efek Indonesia tahun 2016-2019.

Pengujian hipotesis yang disajikan pada Tabel 4, menunjukan hasil nilai signifikansi uji $t$ untuk variabel pengungkapan CSR yaitu $p$-value sebesar 0,053. 
Nilai ini lebih besar dari signifikansi 0,05 dengan koefisien regresi sebesar -33,374 dan sehingga hal ini menjelaskan bahwa pengungkapan CSR tidak memiliki pengaruh terhadap Price to Book Value perusahaan. Sehingga dapat ditarik kesimpulkan bahwa pengungkapan CSR tidak berpengaruh pada Price to Book Value perusahaan, dapat disimpulkan $\mathrm{H}_{0}$ diterima atau $\mathrm{H}_{1}$ ditolak. Berdasarkan hasil analisis regresi yang diperoleh dapat dijelaskan bahwa tinggi rendahnya pengungkapan CSR tidak berpengaruh terhadap naik atau turunnya PBV perusahaan. Hal ini tidak sesuai dengan teori persinyalan yang membahas mengenai informasi yang diberikan oleh suatu perusahaan berupa pengungkapan CSR serta reaksi yang ditunjukkan oleh para investor atas sinyal yang diterima dan diberikan oleh perusahaan (Prajanto \& Pratiwi, 2017). Informasi yang dipublikasikan oleh perusahaan seperti pengungkapan CSR dalam laporan tahunan tidak terlalu menjadi sinyal yang baik bagi investor dalam keputusan investasi, melainkan sebagaian besar investor hanya mengedepankan faktor keuangan. Investor kurang memperdulikan faktor sosial dan lingkungan. Hasil penelitian ini juga tidak sejalan dengan adanya stakeholder theory yang membahas bahwa suatu perusahaan beroperasi bukan hanya untuk kepentingan perusahaan itu namun harus memberikan manfaat kepada stakeholdernya (Lindawati \& Puspita, 2015). Pengungkapan CSR dapat dipertimbangkan oleh investor dalam keputusan investasi, namun berdasarkan hasil penelitian ini, pengungkapan CSR yang dilakukan oleh perusahaan tidak direspon secara positif oleh investor. berdasarkan analisis statistik deskriptif dalam penelitian ini, nilai rata-rata pengungkapan CSR perusahaan sebesar 0,523 menunjukan bahwa pengungkapan CSR yang diungkapkan oleh perusahaan dalam laporan tahunan yang ditujukan kepada masyarakat dan pemangku kepentingan masih jauh dari standar yang telah ditetapkan. Oleh karena itu perusahaan belum dapat memberikan manfaat secara maksimal terhadap para stakeholder. Hasil penelitian ini mendukung penelitian (Worokinasih \& Zaini, 2020) dan (Putri et al., 2016).

Variabel interaksi Pengungkapan CSR*GCG yang disajikan pada Tabel 4. dengan koefisien regresi sebesar 0,548 dengan thitung sebesar 2,842 dan nilai signifikansi yaitu p-value sebesar 0,007. Nilai ini lebih kecil dari signifikansi 0,05 Sehingga hal ini menjelaskan bahwa variabel GCG mampu mem perkuat pengaruh pengungkapan CSR pada Price to Book Value perusahaan. Hasil tersebut menjelaskan bahwa pengungkapan CSR akan meningkatkan Price to Book Value perusahaan pada saat indeks GCG perusahaan meningkat. Dapat disimpulkan bahwa $\mathrm{H}_{2}$ diterima. Berdasarkan hasil analisis regresi yang diperoleh dapat dijelaskan bahwa Good Corporate Governance mengharuskan diterapkannya tata kelola perusahaan yang baik yang mencerminkan kemampuan manajemen dalam mengatur aset dan modal perusahaan sehingga mampu menarik para investor.

Kinerja perusahaan akan meningkat menjadi lebih baik apabila perusahaan menerapkan Good Corporate Governance, dengan penerapan Good Corporate Governance, maka akan dapat meningkatkan aktivitas CSR yang dilakukan perusahaan. Hasil penelitian ini mendukung agency theory. Teori keagenan (agency theory) mendefinisikan terkait hubungan antara principal (pemilik) dengan agent (manajemen) yang terikat dalam suatu kontrak. Principal memberi wewenang kepada agent untuk menjalankan perusahaan sehingga 
mampu mencapai tujuan yang telah ditetapkan. Hubungan antara principal dan agent ini, merupakan hal mendasar bagi praktek penerapan Good Corporate Governance secara luas. Serta didukung oleh Pedoman Umum Good Corporate Governance Indonesia yang menjelaskan terciptanya tanggungjawab perusahaan pada masyarakat dan lingkungan merupakan salah satu tujuan dari pelaksanaan GCG. Kegiatan ini memiliki tujuan dengan memaksimalkan keuntungan suatu perusahaan dengan tetap memperhatikan para stakeholdernya. Seluruh hal tersebut akan terlaksana dengan baik apabila perusahaan menerapkan tata kelola perusahaan yang baik (Good Corporate Governance). Hasil penelitian ini mendukung penelitian (Gde et al., 2013) dan (Purnamaningsih \& Wirawati, 2014).

\section{SIMPULAN}

Simpulan yang dapat ditarik berdasarkan hasil dan pembahasan yang sudah dijelaskan yaitu pengungkapan corporate social responsibility berpengaruh negatif dan tidak signifikan pada Price to Book Value perusahaan yang terdaftar di Bursa Efek Indonesia tahun 2016-2019. Good Corporate Governance memperkuat pengaruh pengungkapan corporate social responsibility pada Price to Book Value perusahaan yang terdaftar di Bursa Efek Indonesia tahun 2016-2019. Penelitian ini tidak terlepas dari keterbatasannya, sehingga terdapat beberapa saran agar keterbatasan tersebut dapat diperbaiki pada penelitian selanjutnya, yaitu tidak hanya mempergunakan variabel pengungkapan corporate social responsibility dan Good Corporate Governance yang mempengaruhi PBV perusahaan. Peneliti menyarankan bagi peneliti selanjutnya untuk melakukan penambahan variabel independen lainnya yang bisa berkorelasi dengan PBV perusahaan seperti menambahkan variabel yang mengindikasikan faktor keuangan seperti kinerja keuangan yang mempengaruhi PBV perusahaan. Periode penelitian yang dilakukan juga terbatas yaitu hanya menggunakan 4 periode dengan rentang tahun 2016-2019 sehingga memiliki jumlah sampel relatif sedikit, sehingga peneliti menyarankan peneliti selanjutnya untuk memperpanjang periode pengamatan sehingga dapat memberikan hasil penelitian yang baik dan relevan.

\section{REFRENSI}

Ardhita, Ayu Nurul \& Toto Sugiharto. 2017. Direct and Indirect Effect of Gcg Implementation Intensity Through Csr Implementation Intensity on Media Exposure and Financial Performance of Food and Beverage Firms Listed in Indonesia Stock Exchange 26(7), pp. 1-16.

Ardimas, W., Ekonomi, F., \& Gunadarma, U. (2014). Pengaruh Kinerja Keuangan Dan Corporate Social Responsibility Terhadap Nilai Perusahaan Pada Bank. BENEFIT Jurnal Manajemen Dan Bisnis, 18, 57-66. https:/ / doi.org/10.14414/jbb.v5i2.547

Ardimas, Wahyu. 2014. "Pengaruh Kinerja Keuangan Dan Corporate Social Responsibility Terhadap Nilai Perusahaan Pada Bank." Benefit Jurnal Manajemen Dan Bisnis 18, hal. 57-66.

Asmeri, R., Alvionita, T. \& Gunardi, A. (2017). CSR Disclosures In The Mining Industry: Empirical Evidence From Listed Mining Firms In Indonesia. Indonesian Journal of Sustainability Accounting and Management, 1(1), pp.16.

Awuy, Vinta Paulinda 2016. "Pengaruh Pengungkapan Corporate Social 
Responsibility ( CSR ) Terhadap Earnings Response Coefficient ( ERC ) ( Suatu Studi Empiris Pada Perusahaan Pertambangan Yang Terdaftar Di Bursa Efek Indonesia Pada Tahun 2010-2013 )." Jurnal Akuntansi Dan Keuangan 18(1), hal.15-26.

Badjuri, A. (2011). Faktor-Faktor Fundamental, Mekanisme Corporate Social Responsibility (CSR) Perusahaan Manufaktur dan Sumber Daya Alam di Indonesia. Dinamika Keuangan Dan Perbankan, 3(1), 38-54.

Bayu, A. N., Putra, D., \& Wirakusuma, M. G. (2015). Pengaruh Pengungkapan Corporate Social Responsibility Pada Nilai Perusahaan Dengan Profitabilitas Sebagai Pemoderasi. Jurnal Akuntansi Universitas Udayana, 13(2), 2302-8556.

Bukhori, Iqbal \& Raharja. 2012. "Pengaruh GCG Dan Ukuran Perusahaan Terhadap Kinerja Perusahaan (Studi Empiris Pada Perusahaan Yang Terdaftar Di BEI)." Dipenogoro of Journal Accountign, hal.17-55

Cahyandito, Martha Fani \& Oktovianus Nawa Pau. 2017. "The Importance of Considering Gcg and Csr While Pursuing Corporate Share Value." Jurnal Bisnis Dan Manajemen 18(02), pp.21-33.

Dewi, I., Handayani, S. R., \& Nuzula, N. F. (2014). Pengaruh Struktur Modal Terhadap Nilai Perusahaan (Studi Pada Sektor Pertambangan Yang Terdaftar Di Bei Periode 2009-2012). Jurnal Administrasi Bisnis S1 Universitas Brawijaya, 17(1), 85090.

Dewi Ariasih, Ni Putu \& I. Ketut Yadnyana. 2018. “Pengaruh Profitabilitas Pada Nilai Perusahaan Dengan Corporate Social Responsibility Sebagai Variabel Moderasi." E-Jurnal Akuntansi 22(2), hal. 1600-1625.

Dianawati, Cici Putri \& Siti Rokhmi Fuadati. 2016. "Pengaruh CSR Dan GCG Terhadap Nilai Perusahaan: Profitabilitas Sebagai Variabel Intervening." Jurnal Ilmu Dan Riset Manajemen 5(1), hal. 1-20.

Ery, Yanto. 2018. "Effect of Corporate Social Responsibility and Good Corporate Governance on the Value of Company with Profitability as Moderating Variables." JAAF (Journal of Applied Accounting and Finance) 2(1), pp. 36.

Fanti, Luciano \& Domenico Buccella. 2017. "The Effects of Corporate Social Responsibility on Entry." Economia e Politica Industriale 44(2), pp. 259-66.

Gozali, Nathalia. 2012. "Dampak Penerapan Prinsip-Prinsip Good Corporate Governance Terhadap Kinerja Perusahaan." JURNAL ILMIAH MAHASISWA AKUNTANSI 1(4), hal. 49-55.

Gde, C., Putra, B., Rasmini, N. K., Bagus, I., \& Astika, P. (2013). Volume.02.No.05. Tahun 2013. 05,338-353.

Harahap, H. P. (2018). The Influence of Information Asymmetry on Earnings Management With Good Corporate Governance (GCG) as the Moderating variable. The Indonesian Accounting Review, 7(1), 61. https:/ / doi.org/10.14414/tiar.v7i1.685

Hidayati, E. E. (2010). Analisis Pengaruh Der, Dpr, Roe Dan Size Terhadap Pbv Perusahaan Manufaktur Yang Listing Di Bei Periode 2005-2007. Jurnal Bisnis Strategi, 19(2), 166-174. https:/ /doi.org/10.14710/jbs.19.2.166-174

Lindawati, Ang Swat Lin \& Marsella Eka Puspita. 2015. “Corporate Social Responsibility: Implikasi Stakeholder Dan Legitimacy Gap Dalam Peningkatan Kinerja Perusahaan." Jurnal Akuntansi Multiparadigma 4(6) hal. 157-74. 
Mahardhika, B. W., \& Roosmawarni, A. (2016). Analisis Karakteristik Perusahaan Yang Mempengaruhi Nilai Perusahaan Pada Perusahaan Manufaktur Yang Terdaftar di Bursa Efek Indonesia (BEI) Tahun 2010-2014. Balance, XIII(2), 2347.

Marlina, T. (2013). Pengaruh Earning Per Share, Return On Equity, Debt To Equity Ratio dan Size Terhadap Price To Book Value. Jurnal Ilmiah AkuntansiKesatuan,1(1),59-72.

https://www.researchgate.net/publication/329364016_Pengaruh_Earning Per_Share_Return_On_Equity_Debt_To_Equity_Ratio_dan_Size_Terhadap_ Price_To_Book_Value_Tri_Marlina

Melani, S., \& Wahidahwati. (2017). Pengaruh CSR dan GCG Terhadap Nilai Perusahaan Dengan Profitabilitas Sebagai Variabel Moderating. Jurnal Ilmu Dan Riset Akuntansi, 6(10), 1-24.

Nahda, K., \& Harjito, D. A. (2011). Pengaruh Corporate Social Responsibility terhadap Nilai Perusahaan dengan Corporate Governance sebagai Variabel Moderasi. Jurnal Siasat Bisnis, 15(1), 1-12. https:// doi.org/10.20885/jsb.vol15.iss1.art1

Pertiwi, T. K., \& Pratama, F. M. I. (2011). Pengaruh Kinerja Keuangan, Good Corporate Governance Terhadap Nilai Perusahaan Food and Beverage. JurnalManajemenDanKewirausahaan, https:/ / doi.org/10.9744/jmk.14.2.118-127

14(2).

Prajanto, A., \& Pratiwi, R. D. (2017). Analisis Nilai Perusahaan Manufaktur Di Indonesia Dari Perspektif Kinerja Keuangan. Jurnal Akuntansi Indonesia, 6(1), 13. https:/ / doi.org/10.30659/jai.6.1.13-28

Purnamaningsih, D., \& Wirawati, N. gusti putu. (2014). Pengaruh return on asset, struktur modal, price to book value dan Good Corporate Governance pada return saham. E-Jurnal Akuntansi Universitas Udayana, 1(9), 1-16.

Putri, A. K., Sudarma, M., \& Purnomosidhi, B. (2016). Pengaruh Corporate Social Responsibility terhadap Nilai Perusahaan dengan Ukuran Perusahaan dan Jumlah Dewan Komisaris sebagai Variabel Pemoderasi (Studi pada Perusahaan Manufaktur yang terdaftar Bursa Efek Indonesia). Jurnal Aplikasi Manajemen, 14(2). https://doi.org/10.18202/jam23026332.14.2.16

Savitri, N. L. A., \& Mimba, N. P. S. H. (2016). Kemampuan Profitabilitas dan Grow th Opportunity Memoderasi Pengaruh Pengungkapan Corporate Social Responsibility pada Nilai Perusahaan. E-Jurnal Ekonomi Dan Bisnis Universitas Udayana, 5(11), 3765-3792.

Siboro, D. T. (2007). Hubungan Good Corporate Governance (GCG) Dengan Pengungkapan Laporan Keuangan. Fokus Ekonomi: Jurnal Ilmiah Ekonomi, 2(2), 17-29.

Silalahi, S. (2014). Pengaruh Corporate Social Responsibility (CSR) Disclosure, Beta Dan Price To Book Value (PBV) Terhadap Earnings Response Coefficient (ERC) (Studi Empiris Pada Perusahaan Manufaktur Yang Terdaftar Di Bursa Efek Indonesia). Jurnal Ekonomi Universitas Riau, 22(01), 8717.

Suffah, R., \& Riduwan, A. (2016). Pengaruh Profitabilitas, Leverage, Ukuran Perusahaan dan Kebijakan Dividen Pada Nilai Perusahaan. Jurnal Ilmu Dan Riset Akuntansi, 5(2), 1-17. https:/ / ejournal.stiesia.ac.id/jira/article/download/1634/1595 
Sunarsih, N. M., Dewi, N. P. S., \& Kireina, M. N. N. A. (2019). Analysis Of Factors Effecting The Firm Value Factors That Effect The Firm Value. International Journal of Applied Business and International Management, 4(3), 94-103. https:// doi.org/10.32535/ijabim.v4i3.687

Susanto, P. B., \& Subekti, I. (2017). Pengaruh Corporate Social Responsibility Dan Good Corporate Governance Terhadap Nilai Perusahaan (Studi Pada Sektor Pertambangan Di Bursa Efek Indonesia). Keberlanjutan, 2(1), 498. https:/ / doi.org/10.32493/keberlanjutan.v2i1.y2017.p498-527

Umbara, D., \& Suryanawa, I. (2014). Pengaruh Pengungkapan Tanggung Jawab Sosial Pada Nilai Perusahaan. E-Jurnal Akuntansi Universitas Udayana, 9(2), 410-424.

Wijaya, M. (2012). Analysis of Insect Hormones by Means of A Radial Compression Separation System. JURNAL ILMIAH MAHASISWA AKUNTANSI, 6(2), 291-299. https: / / doi.org/10.1080/01483918308066890

Worokinasih, S., \& Zaini, M. L. Z. B. M. (2020). The mediating role of corporate social responsibility (CSR) disclosure on Good Corporate Governance (GCG) and firm value. Australasian Accounting, Business and Finance Journal, 14(1 Special Issue), 88-96. https:// doi.org/10.14453/ aabfj.v14i1.9 